\title{
Highly refractory mantle beneath anomalously thin slow-spreading oceanic crust in the Masirah Ophiolite (SE Oman)
}

\author{
MAX N JANSEN ${ }^{1}$, CHRISTOPHER J MACLEOD ${ }^{1}$, JOHAN \\ LISSENBERG $^{1}$ AND IAN PARKINSON $^{2}$ \\ ${ }^{1}$ Cardiff University \\ ${ }^{2}$ University of Bristol \\ Presenting Author: jansenmn@cardiff.ac.uk
}

Melt supply at mid-ocean ridges (MOR) exercises a first order control on oceanic crustal accretion and the resulting lithospheric architecture, and is ultimately a function of the amount of melt produced in the underlying mantle. Slow-spreading ridges $(<40$ $\mathrm{mm} / \mathrm{yr}$ full spreading rate) represent $50 \%$ of the present-day MOR system and are generally thought to have a variable but reduced melt supply compared to their fast-spreading counterparts, leading to heterogeneous crustal accretion that significantly departs from the original Penrose model [1]. Establishing the relationship between the degree of melting, melt supply and resulting crustal architecture is not straightforward, however. Because full cross-sections of oceanic lithosphere are rare, current models of lithospheric architecture often lack constraints on the thickness of the igneous crust produced at slow-spreading ridge segments. Furthermore, mantle is typically exposed where crust is dismembered or absent, making it difficult to establish a direct relationship between mantle melting and crustal magmatism.

Ophiolites can be useful analogues since they allow the crustal and mantle geochemistry to be linked to the 3D architecture of the lithosphere. Many ophiolites originated in supra-subduction zone environments, however, where $\mathrm{H}_{2} \mathrm{O}$ affects the melting regime. The Masirah Ophiolite in Oman is an important exception, as it formed in an uncontroversial tectonic setting during the opening of the proto-Indian Ocean at a true slowspreading MOR at $150 \mathrm{Ma}$ [2]. Masirah has a thin $(<2.5 \mathrm{~km})$ igneous crust with mid-ocean ridge basalts (MORB) of normal to enriched trace element compositions, yet the mantle section is highly refractory suggesting large volumes of melt extraction. We propose that the upwelling of an ancient domain of depleted mantle led to an overall reduced melt supply and a higher proportion of melts from fertile mantle components relative to those from the depleted peridotites. Such refractory domains may be common in the present-day upper mantle underneath MORs and as a result may be a key factor in understanding the variations in lithospheric architecture and MORB compositions that occur along slow-spreading ridges.

1. Cannat, M. JGR 98, 4163-4172 (1993)

2. Peters, Tj. Geol Soc Am Spec Pap 349, 525-536 (2000) 